\title{
Kajian Perilaku Sehat Pelanggan Restoran di saat Pandemi Studi Kasus: Restoran Cepat Saji di Surabaya
}

\author{
Vippy Dharmawan ${ }^{1}$, Nanik Rachmaniyah ${ }^{2}$ \\ ${ }^{1}$ Universitas Muhammadiyah Surabaya \\ ${ }^{2}$ Departemen Desain Interior, Institut Teknologi Sepuluh Nopember, Surabaya \\ masvippy@gmail.com ${ }^{1}$, rachmaniyah@gmail.com ${ }^{2}$
}

\begin{abstract}
ABSTRAK
Kajian hubungan antara setting fisik dan perilaku manusia yang ada di dalamnya cukup banyak dilakukan. Penelitian-penelitian tersebut banyak bermanfaat dalam menyusun desain arsitektur atau pun lingkungan binaan lainnya. Penelitian-penelitian terdahulu yang mengkaji hubungan kedua aspek tersebut telah banyak dilakukan di ruang-ruang publik, dan dengan setting beragam termasuk diantaranya adalah ruang publik restoran. Namun demikian kebanyakan penelitian tersebut dilakukan dalam situasi normal. Penelitian ini mengkaji hubungan setting fisik restoran dan perilaku sehat pelanggannya saat situasi new normal pasca pandemi covid-19 melanda Indonesia. Tujuannya adalah untuk mengetahui pengaruh setting fisik restoran terhadap perilaku sehat pelanggan. Penelitian dilakukan secara deskriptif kualitatif pada tiga buah restoran yang berada di kota Surabaya pada periode bulan Mei hingga Juni 2020. Metode yang digunakan adalah observasi langsung di ketiga restoran tersebut, dan dilakukan saat restoran sedang beroperasi. Hasil penelitian menunjukkan bahwa pelanggan cenderung lebih disiplin dalam berperilaku sehat saat berada di restoran yang menyediakan fasilitas protokol kesehatan secara lengkap, yaitu: fasilitas atau peralatan cuci tangan, signage yang jelas, dan setting perabot sesuai jarak sosial. Penelitian juga menunjukkan bahwa peran petugas yang memandu pengunjung untuk tetap konsisten mematuhi protokol kesehatan sangat dominan.
\end{abstract}

Kata kunci: Covid-19; Perilaku Sehat; Restoran

\section{ABSTRACT}

Studies on correlation between physical setting and human behavior have been done many times. These studies have been useful in the making of architectural design and other built environment. Previous studies on the correlation of those two aspects have been done in public spaces with various settings, one of which is in restaurants. However, those studies were done in normal situation before Covid-19 pandemic. This study looks into the correlation between restaurants physical setting and visitors' health behavior in time of covid-19 pandemic in Indonesia. The purpose is to find out the impact of restaurant physical setting on visitors' health behavior. This study was done in qualitative descriptive manner on three restaurants in Surabaya in May to July 2020. The method that was used is direct observation in the three restaurants. Observation was done when the restaurants were working. The result shows that visitors's tend to be more disciplined in term of health behavior when the restaurant provides complete health facilities, such as: washbasin or any other handwashing facility, clear signage, and furniture settings according to safe social distance. The study also shows that attendants play dominant role to make sure visitors' obey the safe and health protocol.

Keyword: Covid-19; Health Behavior; Restaurant

\section{PENDAHULUAN}

Awal tahun 2020 dunia dikejutkan oleh wabah virus covid-19 yang selanjutnya berkembang menjadi pandemi dan melanda hampir seluruh negara di dunia. Covid-19 atau corona virus disease 2019 adalah jenis penyakit baru yang disebabkan oleh infeksi virus severe acute respiratory syndrome coronavirus 2 (SARS-COV-2) atau yang dikenal dengan novel coronavirus (2019-nCoV). Penularan penyakit ini dapat terjadi melalui droplet (percikan) pada saat orang yang terinfeksi virus berbicara, batuk, atau bersin. Selain itu penularan juga dapat 
terjadi melalui kontak fisik (sentuhan atau jabat tangan) dengan penderita, dan juga saat seseorang menyentuh wajah, mulut, dan hidung dengan tangan yang terpapar virus Corona (Singhal, 2020). Adapun gejala klinisnya adalah seperti gejala flu biasa (demam, batuk, pilek, nyeri tenggorokan, nyeri otot, nyeri kepala) hingga komplikasi berat (diare dan pneumonia) yang kemudian menyebabkan kematian (Huang C, Wang Y, 2020).

Wabah ini dilaporkan pertama kali di kota Wuhan - China pada akhir Desember 2019. China kemudian menjadi negara pertama yang mengalami wabah virus tersebut. Wabah terus berkembang ke seluruh dunia, dan pada 11 Maret 2020 WHO secara resmi mengumumkan wabah virus corona (covid-19) sebagai pandemi. Hingga pertengahan Juli 2020 pandemi ini telah memakan korban lebih dari 593.000 jiwa dan 14 juta kasus positif. Pada waktu yang sama di Indonesia, covid-19 telah merenggut 3.957 jiwa dan 83.130 kasus terkonfirmasi positif. Ketika vaksin covid-19 tidak dapat segera ditemukan dan pandemi memasuki bulan ketiga masyarakat dunia menjadi sadar bahwa kondisi ini akan berlangsung lama. Mereka mau tidak mau harus menghadapi kenyataan dimana mereka harus hidup bersama pandemi selama berbulan-bulan bahkan hingga tahunan. Saat itu muncullah istilah baru yaitu era new normal, yang bermakna masa dimana masyarakat harus hidup bersama dengan virus tersebut.

Pada era new normal terjadi perubahan pada hubungan antar manusia maupun antara manusia dengan lingkungannya. Organisasi kesehatan dunia atau WHO pun mengkampanyekan perilaku-perilaku sehat pada masyarakat untuk mencegah penularan covid19, seperti berdiam di rumah saja (stay at home), menjaga jarak (social distancing), pakai masker, dan cuci tangan pakai sabun. Perilaku sehat ini pun menjadi suatu keharusan saat seseorang beraktivitas di ruang-ruang publik seperti kantor, pusat kebugaran, bioskop, dan kafe atau restoran. Fenomena era new normal ini menarik para ilmuwan untuk diteliti. Restoran sendiri misalnya, menjadi tempat yang menarik untuk dilakukannya studi tentang hubungan antara lingkungan fisik dan perilaku sehat seseorang. Ini karena ia menjadi salah satu tempat yang dikunjungi oleh banyak orang dari berbagai kalangan yang bisa saja menularkan atau membawa virus covid-19 tanpa mereka sadari.

Selama ini studi tentang pengaruh lingkungan fisik terhadap perilaku manusia sudah cukup banyak dilakukan. Studi-studi tersebut sudah banyak memberikan pemahaman pada para peneliti, arsitek, serta perancang lingkungan binaan tentang elemen-elemen apa saja dalam suatu lingkungan fisik yang mempengaruhi perilaku, dan perlu menjadi bahan rujukan dalam merancang lingkungan binaan (Aghostin-sangar, 2007). Dapat dikatakan bahwa studi pertama tentang suatu lingkungan fisik yang mempunyai fungsi komersial dilakukan oleh Kotler. Ia mengemukakan bahwa ruang yang dirancang dengan baik akan menghasilkan efek emosi yang spesifik pada pelanggan, yang pada akhirnya akan berpengaruh pada kehendak mereka untuk berbelanja. Pengaruh tersebut didasarkan pada beberapa sensasi yang pada dasarnya dimiliki oleh manusia, yaitu : penglihatan, pendengaran, penciuman atau aroma, sentuhan, dan rasa (Kotler P, 1973). Selanjutnya Bitner yang meneliti pengaruh musik pada perilaku pelanggan supermarket mengemukakan tiga aspek suasana ruang atau yang diistilahkan olehnya sebagai servicescape. Tiga aspek inilah yang menurutnya sebagai suatu hal yang harus dipertimbangkan dalam rancangan. Yaitu kondisi ambien (misal temperatur, pencahayaan, kebisingan, musik, aroma), layout spasial (misal perabot, peralatan, mesin-mesin, termasuk bentuk dan ukurannya) dan lainnya seperti simbol, penanda, dan artefak lainnya yang sejenis (Bitner, 1992).

Sejalan dengan itu, penelitian tentang pengaruh lingkungan fisik terhadap perilaku pelanggan restoran juga cukup banyak dilakukan di berbagai negara. Pada akhir tahun 2014 hingga awal 2015 dilakukan sebuah studi yang menyasar pelanggan dari ratusan restoran di Turki. Tujuan studi ini adalah untuk mengetahui sejauh mana pentingnya lingkungan fisik restoran bagi pelanggan, dan juga untuk mengetahui hubungan antara lingkungan fisik restoran 


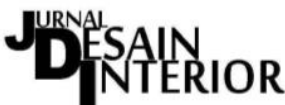

dengan karakteristik pelanggan. Hasil studi tersebut mengemukakan bahwa ada enam faktor yang menjadi pertimbangan pelanggan dalam memilih restoran, yaitu : servis dari pelayan, keindahan ruangan, penataan lay out ruangan, lingkungan ambience, tata letak meja kursi, dan pencahayaan. Penelitian ini juga mengemukakan bahwa pertimbangan faktor-faktor tersebut juga dipengaruhi oleh karakteristik demografi dari pelanggan restoran(Tuzunkan \& Albayrak, 2016). Studi serupa sebelumnya juga dilakukan untuk mengetahui pengaruh persepsi pelanggan tentang lingkungan fisik restoran terhadap kepuasan dan loyalitas mereka (Ryu \& Han, 2011).

Sementara itu di Indonesia juga tidak sedikit kajian tentang hubungan lingkungan fisik restoran dengan perilaku pelanggannya. Sebuah penelitian yang dilakukan Izzati dan kawankawan pada beberapa kafe di Bandung bertujuan untuk mengetahui faktor-faktor yang dapat mempengaruhi kenyamanan duduk pelanggan kafe. Hasil penelitian tersebut mengungkapkan bahwa faktor-faktor yang mempengaruhi alasan pelanggan untuk memilih lokasi duduk adalah faktor lokasi atau posisi kursi, view atau pemandangan, dan privasi. Pelanggan menyukai letak meja kursi yang memungkinkan mereka bergerak dengan leluasa. Selain itu aspek privasi juga menjadi pertimbangan utama dalam memilih posisi kursi. Banyak pelanggan lebih suka memilih posisi yang memungkinkan terbentuknya privasi bagi mereka atau kelompoknya. Hampir semua pelanggan yang datang berdua atau berkelompok akan memilih tempat duduk yang berdekatan atau berhadapan dengan jarak yang dekat. Sementara itu posisi kursi dekat jendela yang mempunyai view bebas keluar juga menjadi favorit pelanggan. (Izzati, Maharani, \& Wiyancoko, 2017). Kecenderungan pelanggan yang memilih kursi dekat dengan jendela ini juga ditemukan oleh Dharmawan dalam penelitian di sebuah resto cepat saji di kota Surabaya. (Dharmawan, Conytin, \& Rachmaniyah, 2018).

Semua penelitian yang disebutkan di atas tersebut dilakukan pada saat situasi dan kondisi yang normal. Sementara jika merujuk pada situasi pandemi seperti telah diuraikan di atas, yang saat ini masih terus berlangsung, dibutuhkan pengetahuan-pengetahuan baru tentang bagaimana seharusnya respon bangunan atau lingkungan binaan terhadap situasi pandemi tersebut. Selain itu juga diperlukan pengetahuan-pengetahuan tentang bagaimana seseorang atau juga sekelompok orang bertingkah laku di ruang publik pada saat pandemi berlangsung.

Pada sisi lain pengetahuan tentang pentingnya lingkungan yang sehat juga diperlukan dalam merancang suatu lingkungan binaan. Konsep healthy setting sudah dikenal cukup lama. Doorik dan kawan-kawan, dalam buku yang ditulis oleh Batara mengemukakan bahwa konsep tersebut merupakan suatu pengaturan tempat atau konteks sosial manusia beraktifitas seharihari dimana lingkungan, organisasi, dan faktor pribadi berinteraksi untuk mempengaruhi kesehatan dan kesejahteraan. Tujuannya adalah untuk mengoptimalkan pencegahan penyakit dengan pendekatan yang holistik. Dengan demikian dalam hal ini setting atau pengaturan lingkungan fisik diciptakan dengan memperhatikan faktor-faktor penentu kesehatan yang terkait dengan aktifitas keseharian setiap orang. (Batara, 2018).

Dengan adanya pengetahuan tentang lingkungan yang sehat diharapkan akan terbentuk perilaku sehat dari masyarakat. Perilaku sehat adalah suatu respon seseorang atau organisme terhadap stimulus yang berkaitan dengan sakit dan penyakit, sistem pelayanan kesehatan, makanan, serta lingkungan. (Notoatmodjo, 2010). Sementara itu kesehatan menurut UU Kesehatan No. 39 tahun 2009 adalah keadaan sehat, baik secara fisik, mental, spritual maupun sosial yang memungkinkan setiap orang untuk hidup produktif secara sosial dan ekonomis.

Dari uraian di atas maka adalah penting untuk mengkaji hubungan setting fisik restoran dengan perilaku sehat pelanggannya saat situasi new normal pasca pandemi covid-19 melanda Indonesia. Tujuannya adalah untuk mengetahui bagaimana hubungan diantara keduanya, 
sehingga pengetahuan yang diperoleh dapat digunakan sebagai rujukan desain di masa-masa mendatang.

\section{METODE PENELITIAN}

Penelitian ini menggunakan metode observasi dengan cara mendeskripsikan elemenelemen fisik restoran yang membentuk milieu atau lingkungan, dan perilaku-perilaku sehat pelanggan. Secara lebih spesifik perilaku sehat dalam hal ini adalah perilaku yang menunjang upaya pencegahan penularan virus covid-19. Penelitian diawali dengan survey pendahuluan untuk menentukan sampel atau lokasi penelitian. Pemilihan sampel berdasarkan pertimbangan segmen pelanggan dan kelengkapan fasilitas pendukung protokol kesehatan. Fasilitas tersebut antara lain berupa (1) petugas pemandu, (2) fasilitas atau peralatan cuci tangan, (3) signage, dan (4) setting perabot sesuai jarak sosial, dan posisi entrance serta exit.

Tiga restoran yang dipilih sebagai sampel mempunyai segmen pelanggan yang sama. Demikian pula dengan cara penjualannya, yaitu cara cepat saji. Dengan demikian bisa didapatkan karakteristik pelanggan yang homogen. Yang pertama adalah restoran cepat saji MD yang berlokasi di Jalan Mulyosari. Kedua adalah restoran BK berlokasi di Jalan Ir. Soekarno., dan yang ketiga adalah restoran AW berlokasi di Jalan Raya Nginden Semolo. Ketiganya berlokasi di Surabaya timur. Pemilihan lokasi sampel ini juga dilakukan dengan pertimbangan untuk mendapatkan segmen pelanggan yang sama.

Selanjutnya pada ketiga restoran tersebut dilakukan kegiatan pengamatan, yang berlangsung pada periode bulan Mei hingga Juni 2020. Hal yang pertama kali diamati adalah setting fisik ruangan. Elemen-elemen pembentuk setting fisik atau milieu diidentifikasi kelengkapan dan kelayakannya. Terdiri dari fasilitas cuci tangan atau wastafel, hand sanitizer, poster atau banner pencegahan penularan, signage petunjuk, pintu exit, penataan meja kursi, dan petugas atau pelayan restoran. Setelah itu masing-masing diberi skor nilai. Skor tertinggi diberikan pada kondisi yang paling layak, sedangkan skor terendah diberikan jika fasilitas tersebut tidak ada.

Kegiatan berikutnya adalah pengamatan perilaku sehat pelanggan. Perilaku yang diamati antara lain meliputi perilaku membersihkan atau mencuci tangan, memakai masker, dan social distancing. Pada tiap lokasi dilakukan setidaknya tiga kali pengamatan baik di saat sepi maupun saat ramai pelanggan. Hasil pengamatan tersebut kemudian dianalisa dan diperbandingkan untuk mengetahui hubungan antara kualitas setting fisik restoran dan perilaku sehat pelanggannya.

\section{HASIL PENELITIAN DAN PEMBAHASAN}

\section{A. Setting Fisik Restoran}

Setting fisik yang membentuk milieu di ketiga restoran memiliki keserupaan, namun menunjukkan beberapa perbedaan dalam kelengkapan maupun kualitasnya. Misalnya tidak semua restoran menyediakan petugas pemandu di pintu masuk. Juga hanya ada satu restoran yang menyediakan pintu exit yang terpisah dengan pintu masuk. Hasil pengamatan juga menunjukkan bahwa tiap elemen memperlihatkan kualitas atau kinerja yang berbeda. Agar mudah dianalisa, peneliti menggunakan penilaian skor untuk mengidentifikasi kualitasnya. Mulai dari skor empat hingga satu (Tabel 1). Pengamatannya dilakukan area per area. Mulai dari area teras, area makan, hingga area konter tempat pelanggan membeli dan mengambil hidangan secara self service. 
Tabel 1. Fasilitas Pendukung Perilaku Sehat

\begin{tabular}{|c|c|c|c|c|c|}
\hline \multirow{2}{*}{ No. } & \multirow{2}{*}{ Fasilitas } & \multicolumn{4}{|c|}{ Skor untuk Kelengkapan dan Kelayakan } \\
\hline & & Skor 4 & Skor 3 & Skor 2 & Skor 1 \\
\hline & Area Entrance: & & & & \\
\hline 1 & Tempat cuci tangan & $\begin{array}{l}\text { ada dan mudah } \\
\text { dijangkau }\end{array}$ & $\begin{array}{c}\text { ada, namun } \\
\text { posisinya jauh } \\
\text { dari jangkauan }\end{array}$ & $\begin{array}{c}\text { ada namun } \\
\text { kurang layak } \\
\text { kondisinya }\end{array}$ & tidak ada \\
\hline 2 & Hand sanitizer & $\begin{array}{l}\text { ada dan mudah } \\
\text { dijangkau }\end{array}$ & $\begin{array}{c}\text { ada, namun } \\
\text { posisinya jauh } \\
\text { dari jangkauan }\end{array}$ & $\begin{array}{l}\text { tidak setiap } \\
\text { saat tersedia }\end{array}$ & tidak ada \\
\hline 3 & Petugas pemandu & $\begin{array}{l}\text { ada, dilengkapi } \\
\text { thermogun, dan } \\
\text { aktif memandu }\end{array}$ & $\begin{array}{c}\text { ada, tidak } \\
\text { dilengkapi } \\
\text { thermogun/ } \\
\text { kurang disiplin }\end{array}$ & $\begin{array}{l}\text { kadang ada, } \\
\text { kadang tidak }\end{array}$ & $\begin{array}{l}\text { tidak ada } \\
\text { petugas }\end{array}$ \\
\hline \multirow[t]{2}{*}{4} & Banner/poster Covid-19 & $\begin{array}{l}\text { ada dan jelas } \\
\text { terlihat }\end{array}$ & $\begin{array}{c}\text { ada, namun } \\
\text { kurang banyak } \\
\text { dan kurang jelas }\end{array}$ & $\begin{array}{l}\text { nyaris tidak } \\
\text { nampak }\end{array}$ & tidak ada \\
\hline & Area Ruang Makan: & & & & \\
\hline 5 & Tempat cuci tangan & $\begin{array}{l}\text { ada dan mudah } \\
\text { dijangkau }\end{array}$ & $\begin{array}{c}\text { ada, namun } \\
\text { posisinya jauh } \\
\text { dari jangkauan }\end{array}$ & $\begin{array}{c}\text { ada namun } \\
\text { kurang layak } \\
\text { kondisinya }\end{array}$ & tidak ada \\
\hline 6 & Hand sanitizer & $\begin{array}{l}\text { ada dan mudah } \\
\text { dijangkau }\end{array}$ & $\begin{array}{c}\text { ada, namun } \\
\text { posisinya jauh } \\
\text { dari jangkauan }\end{array}$ & $\begin{array}{l}\text { tidak setiap } \\
\text { saat tersedia }\end{array}$ & tidak ada \\
\hline 7 & Petugas pemandu & $\begin{array}{l}\text { ada dan cukup } \\
\text { aktif memandu }\end{array}$ & $\begin{array}{l}\text { ada, namun } \\
\text { tidak secara } \\
\text { khusus }\end{array}$ & $\begin{array}{l}\text { kadang ada, } \\
\text { kadang tidak }\end{array}$ & $\begin{array}{c}\text { tidak ada } \\
\text { petugas } \\
\text { khusus utk } \\
\text { memandu }\end{array}$ \\
\hline 8 & Penataan Furnitur & $\begin{array}{l}\text { stiker petunjuk } \\
\text { ada, seluruh kursi } \\
\text { diatur jaraknya }\end{array}$ & $\begin{array}{l}\text { stiker petunjuk } \\
\text { ada, sebagian } \\
\text { besar kursi } \\
\text { diatur jaraknya }\end{array}$ & $\begin{array}{c}\text { stiker } \\
\text { petunjuk ada, } \\
\text { sebagian } \\
\text { kecil kursi }\end{array}$ & $\begin{array}{c}\text { semua kursi } \\
\text { tidak diatur } \\
\text { jaraknya }\end{array}$ \\
\hline 9 & Pintu exit khusus & $\begin{array}{l}\text { ada dan mudah } \\
\text { terlihat }\end{array}$ & $\begin{array}{c}\text { ada namun } \\
\text { kurang nampak }\end{array}$ & $\begin{array}{l}\text { tidak ada } \\
\text { pintu exit, } \\
\text { namun ada }\end{array}$ & $\begin{array}{l}\text { tidak ada } \\
\text { pintu exit }\end{array}$ \\
\hline \multirow[t]{2}{*}{10} & Banner/poster Covid-19 & $\begin{array}{c}\text { ada dan jelas } \\
\text { terlihat }\end{array}$ & $\begin{array}{c}\text { ada, namun } \\
\text { kurang banyak, } \\
\& \text { kurang jelas }\end{array}$ & $\begin{array}{c}\text { nyaris tidak } \\
\text { nampak }\end{array}$ & tidak ada \\
\hline & Area Konter Layanan: & & & & \\
\hline 11 & Signage jarak antrian & $\begin{array}{c}\begin{array}{c}\text { signage jaga jarak } \\
\text { cukup } \\
\text { banyak/jelas }\end{array} \\
\end{array}$ & $\begin{array}{l}\text { signage jaga } \\
\text { jarak sedikit } \\
\text { namun jelas }\end{array}$ & $\begin{array}{l}\text { signage jaga } \\
\text { jarak sedikit } \\
\text { \& tidak jelas }\end{array}$ & $\begin{array}{c}\text { tidak ada } \\
\text { signage jaga } \\
\text { jarak }\end{array}$ \\
\hline 12 & Hand sanitizer & $\begin{array}{l}\text { ada dan mudah } \\
\text { dijangkau }\end{array}$ & $\begin{array}{c}\text { ada, namun } \\
\text { posisinya jauh } \\
\text { dari jangkauan }\end{array}$ & $\begin{array}{l}\text { tidak setiap } \\
\text { saat tersedia }\end{array}$ & tidak ada \\
\hline 13 & Banner/poster Covid-19 & $\begin{array}{l}\text { ada dan jelas } \\
\text { terlihat }\end{array}$ & $\begin{array}{c}\text { ada, namun } \\
\text { kurang banyak, } \\
\& \text { kurang jelas }\end{array}$ & $\begin{array}{l}\text { nyaris tidak } \\
\text { nampak }\end{array}$ & tidak ada \\
\hline
\end{tabular}

Sumber: Data Penulis (2020)

Bagian teras adalah area yang menjadi entrance pelanggan. Keberadaan sarana cuci tangan yang representatif dan mudah dilihat serta dijangkau mendapatkan skor tertinggi. Sedangkan ketiadaan sarana tersebut memperoleh skor terendah. Banner atau signage peringatan pencegahan penularan covid yang jelas terlihat juga mendapatkan skor tertinggi. Sebaliknya yang tidak menyediakannya mendapatkan skor terendah. Selain itu pada bagian pintu masuk ke ruang makan keberadaan petugas pemandu juga mendapatkan penilaian tersendiri. 


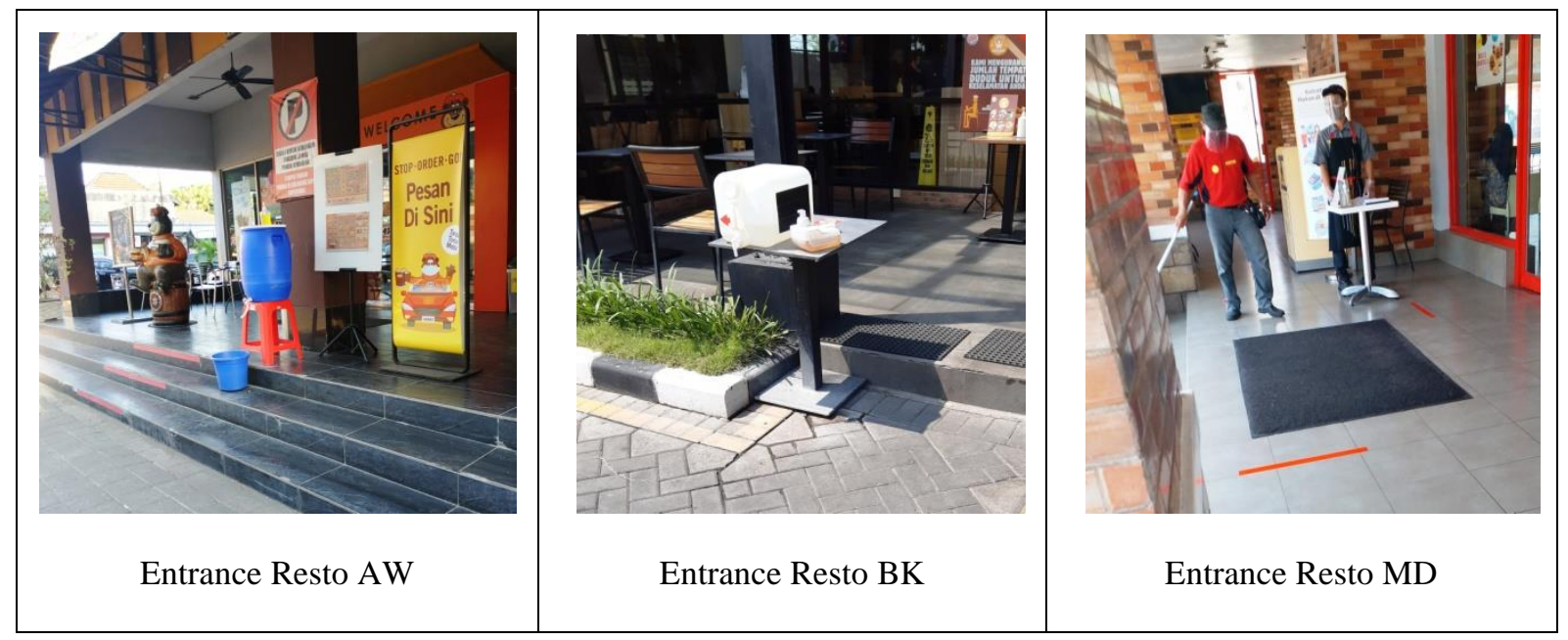

Gambar 1. Perbandingan Fasilitas Cuci Tangan di Entrance Restoran AW, BK, dan MD

Pada Restoran MD (paling kanan) terdapat wastafel dan meja tempat hand sanitizer yang ditunggui petugas Sumber: Dokumentasi Penulis (2020)

Seperti halnya area teras, pada area ruang makan hasil pengamatan menunjukkan adanya elemen-elemen fisik yang dapat menunjang perilaku sehat. Seperti fasilitas cuci tangan, ketersediaan hand sanitizer, penataan meja kursi, banner atau signage peringatan pencegahan penularan covid, dan juga petugas yang mengingatkan pelanggan untuk tetap menjaga jarak aman sesuai ketentuan social distancing. Demikian juga pada area konter, elemen fisik yang dapat menunjang perilaku sehat adalah ketersediaan hand sanitizer, signage jarak antrian, dan banner atau signage peringatan pencegahan penularan covid.

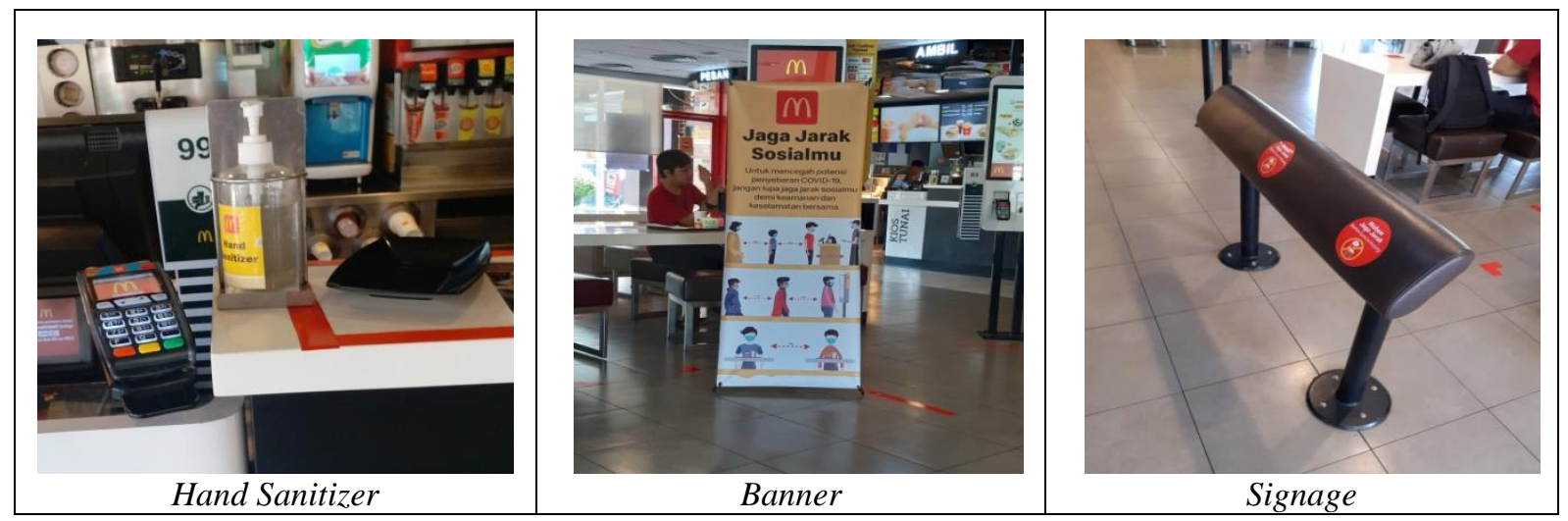

Gambar 2. Beberapa Fasilitas Penunjang Protokol Kesehatan Sumber: Dokumentasi Penulis (2020)

Upaya penataan meja kursi untuk menjaga social distancing nampak dilakukan oleh semua restoran. Baik dengan menempelkan stiker/signage maupun dengan cara menjaga jarak kursi. Secara umum ada tiga cara penataan meja kursi yang dilakukan oleh mereka. Pertama adalah formasi kursi double seat yang memberi kemungkinan sangat besar bagi pelanggan untuk duduk berdekatan. Jarak hanya diatur oleh stiker larangan duduk. Kedua adalah formasi kursi single seat yang jaraknya agak jauh ditambah dengan stiker larangan duduk di kursi/meja. Sedang yang ketiga adalah formasi kursi single seat yang selain jaraknya berjauhan, juga diberi stiker larangan duduk. Formasi ini sangat baik, karena sangat efektif dalam menghalangi pelanggan untuk duduk berdekatan (Gambar 3 kiri, kanan, dan tengah). 


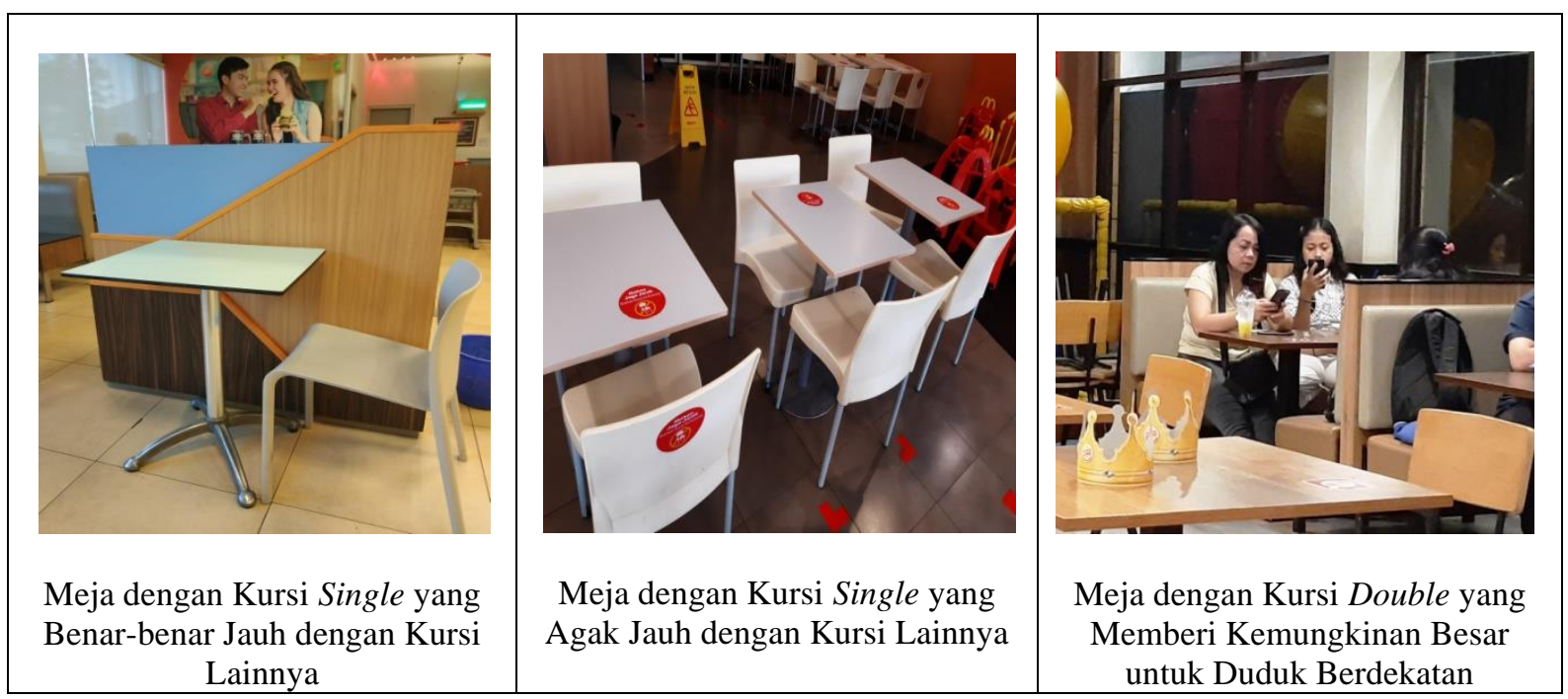

Gambar 3. Beberapa setting Meja Kursi yang Berupaya Menerapkan Jarak Aman Sumber: Dokumentasi Penulis (2020)

Tabel 2 berikut memperlihatkan perbandingan skor fasilitas pendukung perilaku sehat pada restoran $\mathrm{MD}, \mathrm{BK}$, dan $\mathrm{AW}$, dimana restoran $\mathrm{MD}$ memperoleh skor paling tinggi. Ini menandakan bahwa restoran tersebut adalah yang paling lengkap dan layak fasilitasnya. Baik di area entrance, ruang makan, hingga area konter. Sementara restoran BK memperoleh skor sedikit lebih rendah, dan restoran AW adalah yang paling rendah.

Tabel 2. Perbandingan Skor Fasilitas Pendukung Perilaku Sehat

\begin{tabular}{|c|l|c|c|c|}
\hline \multirow{2}{*}{ No. } & \multicolumn{2}{|c|}{ Fasilitas } & \multicolumn{3}{c|}{ Skor } \\
\cline { 3 - 5 } & & Resto MD & Resto BK & Resto AW \\
\hline & Area Entrance: & & & \\
\hline 1 & Tempat cuci tangan & 4 & 3 & 1 \\
\hline 2 & Hand sanitizer & 4 & 4 & 1 \\
\hline 3 & Petugas pemandu & 4 & 3 & 3 \\
\hline 4 & Banner/poster Covid-19 & 4 & 4 & 4 \\
\hline & Area Ruang Makan: & & & 1 \\
\hline 5 & Tempat cuci tangan & 4 & 2 & 1 \\
\hline 6 & Hand sanitizer & 3 & 1 & 3 \\
\hline 7 & Petugas pemandu & 3 & 1 & 1 \\
\hline 8 & Penataan Furnitur & 3 & 1 & 2 \\
\hline 9 & Pintu exit khusus & 4 & 2 & 1 \\
\hline 10 & Banner/poster Covid-19 & & 3 & 1 \\
\hline & Area Konter Layanan: & 4 & 3 & $\mathbf{2 2}$ \\
\hline 11 & Signage jarak antrian & 3 & 3 & $\mathbf{3 3}$ \\
\hline 12 & Hand sanitizer & $\mathbf{4 6}$ & 3 & \\
\hline 13 & Banner/poster Covid-19 & & \\
\hline & & J U M L A H &
\end{tabular}

Sumber: Hasil Observasi Lapangan (2020)

\section{B. Perilaku Sehat}

Pada area teras perilaku sehat yang diperlihatkan pelanggan adalah memakai masker, mencuci tangan, dan menggunakan hand sanitizer. Sedangkan yang diperlihatkan petugas pemandu adalah memeriksa suhu tubuh, mengingatkan untuk memakai masker, dan mencuci tangan atau menggunakan hand sanitizer. 
Perilaku mencuci tangan atau menggunakan hand sanitizer lebih sering terlihat di area teras restoran MD, karena ada arahan dari petugas di pintu masuk yang mempersilakan pelanggan untuk melakukannya sebelum masuk ke area ruang makan. Sedangkan di restoran BK walaupun di area teras disediakan tempat cuci tangan yang cukup representatif, pelanggan hanya kadangkadang saja terlihat mencuci tangannya karena tidak ada arahan dari petugas. Adapun di restoran AW yang tidak menyediakan petugas di pintu masuk, perilaku tersebut hampir tidak pernah terlihat.

Sementara itu di area makan perilaku sehat yang nampak dilakukan pelanggan adalah memakai masker, mencuci tangan, menggunakan hand sanitizer, dan duduk dengan jarak aman 1 meter. Sedangkan perilaku sehat petugas pemandu adalah memberi arahan pada pelanggan untuk duduk di kursi yang telah ditata atau ditandai dalam jarak aman 1 meter. Perilaku petugas pemandu yang seperti ini hanya terlihat di restoran MD saja. Sedangkan di dua restoran lainnya tidak pernah nampak.

Pada restoran MD dan AW perilaku mencuci tangan di area ruang makan cukup sering terlihat. Sedangkan di restoran BK perilaku ini jarang terjadi. Adapun pada penggunaan masker di area ruang makan, pelanggan di restoran $\mathrm{MD}, \mathrm{BK}$, dan $\mathrm{AW}$ memiliki kecenderungan perilaku yang berbeda-beda. Pelanggan restoran MD paling tertib menggunakan masker, berikutnya adalah pelanggan restoran BK, dan yang paling tidak tertib adalah pelanggan restoran AW. Sementara itu kecenderungan penggunaan hand sanitizer sebelum bersantap di area ruang makan ketiga restoran tersebut nampak sama. Hand sanitizer jarang terlihat digunakan di area ini.

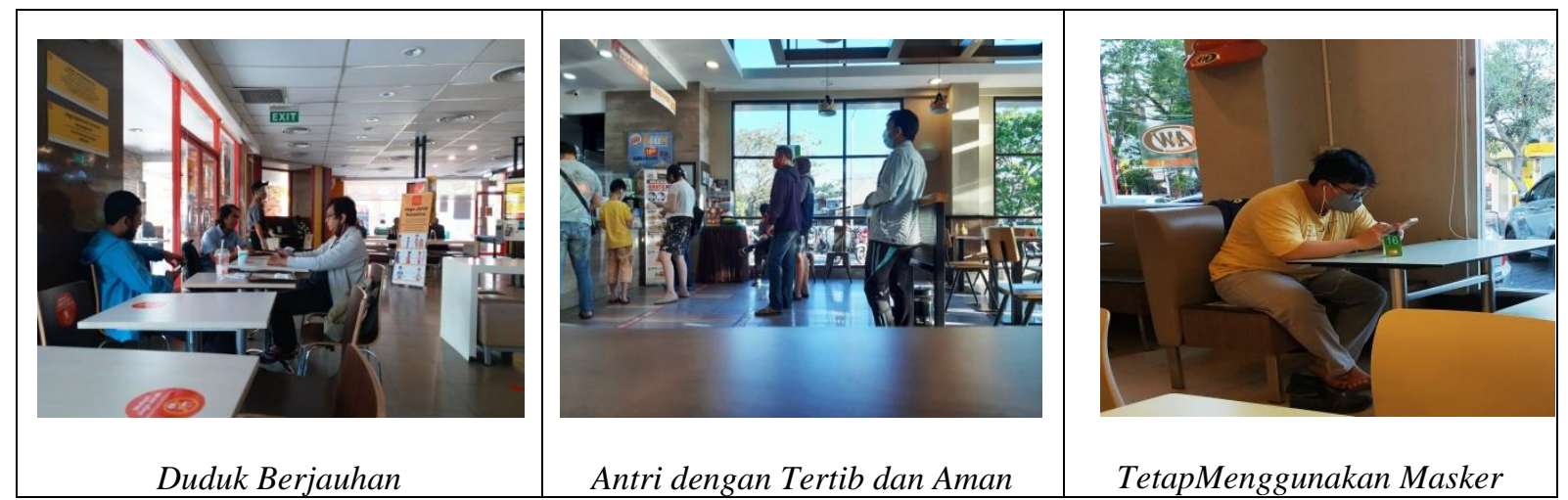

Gambar 4. Beberapa Perilaku Sehat Sesuai Protokol Kesehatan Sumber: Dokumentasi Penulis (2020)

Beralih ke area konter, perilaku yang teridentifikasi di area ini adalah mengantri di depan konter, memakai masker, dan menggunakan hand sanitizer. Hasil pengamatan menunjukkan bahwa pelanggan di ketiga restoran cukup tertib memakai masker saat berada didepan konter. Sebaliknya perilaku menggunakan hand sanitizer jarang terlihat. Apalagi hanya di restoran MD saja yang didapati hand sanitizer yang gampang dilihat dan dijangkau pelanggan. Sementara itu perilaku mengantri di depan konter terlihat berbeda-beda di masing-masing restoran. Pelanggan restoran MD dan BK relatif cukup tertib, dan hal yang sebaliknya terlihat di restoran AW.

Tabel 3 menunjukkan perilaku sehat yang tampak di ketiga restoran. Baik di area teras, area ruang makan, maupun area konter. 
Tabel 3. Perilaku Sehat pada Restoran

\begin{tabular}{|c|c|c|c|c|}
\hline \multirow[b]{2}{*}{ No. } & \multirow[b]{2}{*}{ Pola Perilaku Sehat } & \multicolumn{3}{|c|}{ Skor } \\
\hline & & $\begin{array}{c}\text { Resto } \\
\text { MD }\end{array}$ & $\begin{array}{c}\text { Resto } \\
\text { BK }\end{array}$ & $\begin{array}{c}\text { Resto } \\
\text { AW }\end{array}$ \\
\hline & Area Entrance: & & & \\
\hline 1 & Pelanggan menggunakan masker wajah & 3 & 3 & 3 \\
\hline 2 & Pelanggan mencuci tangannya di wastafel atau kran cuci tangan & 3 & 1 & 0 \\
\hline 3 & Pelanggan menggunakan hand sanitizer & 3 & 1 & 0 \\
\hline 4 & Petugas pemandu memeriksa masker & 3 & 3 & 0 \\
\hline 5 & Petugas pemandu memeriksa suhu dengan thermogun & 4 & 3 & 0 \\
\hline \multirow[t]{2}{*}{6} & Petugas pemandu menggunakan masker wajah & 4 & 4 & 0 \\
\hline & Area Ruang Makan: & & & \\
\hline 5 & Pelanggan mencuci tangannya di wastafel & 2 & 1 & 2 \\
\hline 6 & Pelanggan menggunakan hand sanitizer yang disediakan & 1 & 0 & 0 \\
\hline 7 & Pelanggan menggunakan hand sanitizer yang dibawa sendiri & 1 & 1 & 1 \\
\hline 8 & Pelanggan duduk berjarak, lebih dari 1 meter & 3 & 2 & 2 \\
\hline 9 & Pelanggan menggunakan masker saat tidak makan/minum & 2 & 2 & 2 \\
\hline 10 & Pemandu mengarahkan pelanggan untuk menjaga jarak & 3 & 0 & 0 \\
\hline \multirow[t]{2}{*}{11} & Pelayan/petugas menggunakan masker wajah & 4 & 4 & 2 \\
\hline & Area Konter Layanan: & & & \\
\hline 13 & Pelanggan antri dengan tertib menjaga jarak aman & 3 & 3 & 3 \\
\hline 14 & Pelanggan menggunakan hand sanitizer yang disediakan & 1 & 1 & 1 \\
\hline 15 & Pelanggan menggunakan masker wajah & 3 & 3 & 3 \\
\hline \multirow[t]{2}{*}{16} & Petugas konter menggunakan masker wajah & 4 & 4 & 2 \\
\hline & J U M L A H & 47 & 36 & 21 \\
\hline
\end{tabular}

\section{KESIMPULAN}

Fenomena perbedaan setting fisik di ketiga restoran yang menjadi sampel penelitian menunjukkan bahwa restoran-restoran yang jenis, kelas, dan segmen pengunjungnya sama tidak selalu mempunyai respon yang sama terhadap adanya pandemi. Hal ini terlihat dari baragamnya cara penyediaan fasilitas pendukung perilaku sehat pada masing-masing restoran. Ada yang meresponnya dengan menyediakan fasilitas pendukung yang lengkap, ada yang secukupnya, dan ada pula yang minim.

Hasil penelitian juga menunjukkan bahwa pengunjung cenderung patuh pada protokol kesehatan saat berada di restoran yang menyediakan fasilitas pendukung perilaku sehat dengan lengkap. Selain itu juga nampak bahwa peran petugas yang memandu pengunjung untuk tetap konsisten mematuhi protokol kesehatan sangat dominan.

\section{DAFTAR PUSTAKA}

Aghostin-sangar, V. (2007). Human Behavior in Public Spaces. University of New South Wales.

Batara, A. S. (2018). Healthy Setting Ruang Publik Perkotaan: Sebuah Konsep Terminal Sehat. Makassar: SIGn.

Bitner, M. J. (1992). Using Background Music to Affect the Behaviour of Supermarket Shoppers. Journal of Marketing, 56(2), 57. https://doi.org/10.2307/1252042

Dharmawan, V., Conytin, F., \& Rachmaniyah, N. (2018). Kajian Perilaku dan Interior Restoran

Cepat Saji di Pusat Perbelanjaan. Jurnal Desain Interior, 3(2), 27. https://doi.org/10.12962/j12345678.v3i2.4597

Haryadi, \& Setiawan, B. (2010). Arsitektur Lingkungan dan Perilaku. Yogyakarta: UGM Press. 
Huang C, Wang Y, L. X. (2020). Clinical features of patients infected with 2019 novel coronavirus in Wuhan, China. The Lancet, 395(10223), 497-506. Retrieved from https://www.sciencedirect.com/science/article/abs/pii/S0140673620301835

Izzati, A. W., Maharani, Y., \& Wiyancoko, D. (2017). Relasi Desain dan Tata Letak Sarana Duduk Terhadap Kenyamanan Pengunjung Kafe. Jurnal Desain Interior, 2(1), 55. https://doi.org/10.12962/j12345678.v2i1.2379

Kotler P. (1973). Atmospherics as a marketing tool. Retail, 49, 48-64.

Notoatmodjo, S. (2010). Ilmu Perilaku Kesehatan. Jakarta: Rineka Cipta.

Popov, L., \& Chompalov, I. (2012). Crossing Over: The Interdisciplinary Meaning of Behavior Setting Theory. International Journal of Humanities and Social Science, 2(19), 18-27.

Ryu, K., \& Han, H. (2011). International Journal of Hospitality Management New or repeat customers: How does physical environment influence their restaurant experience? International Journal of Hospitality Management, 30(3), 599-611. https://doi.org/10.1016/j.ijhm.2010.11.004

Singhal, T. (2020). A Review of Coronavirus Disease-2019 (COVID-19). The Indian Journal of Pediatrics, 87(4), 281-286.

Tuzunkan, D., \& Albayrak, A. (2016). The Importance of Restaurant Physical Environment For Turkish Customers. Journal of Tourism Research \& Hospitality, 05(01), 1-7. https://doi.org/10.4172/2324-8807.1000154 